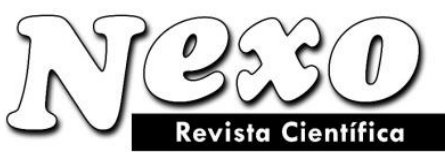

Vol. 34, No. 02, pp. 916-925/Junio 2021

\title{
Current state and development prospects of the construction industry
}

\section{Estado actual y perspectivas de dessarollode la industria de la construcción}

\author{
Kheda Murtazova $^{1, *}$, Salambek Aliyev ${ }^{2}$ \\ ${ }^{1}$ Chechen State University, Grozny, Russian Federation. \\ ${ }^{2}$ Grozny State Oil Technical University named after Academician M.D. Millionshchikova, Grozny, \\ Russian Federation. \\ *salamova_chgu@mail.ru
}

(recibido/received: 03-febrero-2021; aceptado/accepted: 15-abril-2021)

\begin{abstract}
The relevance of the research topic is due to the fact that construction companies in a difficult period in 2020 faced risk problems and many construction companies declared themselves bankrupt during this period. The globalization of the modern world defines more and more severe challenges for national economies around the world. Taking into account the modern patterns of development of the world economy, it is important for the national economy of each state to have a competitive advantage, thanks to which it will develop. The purpose of this article is to analyze the current state of the construction industry both in Russia and throughout the world, analyze existing problems, and develop measures aimed at solving them. In studying the economic situation of this industry, indicators such as volume dynamics were considered. construction works and the dynamics of the number of construction organizations. In addition, the work identified factors that limit the activities of construction organizations and the prospects for the development of the construction industry both in Russia and around the world. This paper defines actions to solve the problems of the construction industry, and also determines the expected results of the implementation of these measures. The construction industry also sets the level of economic development, is a very important sector in the economy of many countries of the world. The development of construction services all over the world has been gaining momentum in the past few decades and is developing very dynamically. However, the construction industry is very sensitive to even minor fluctuations in the global market. The subject of the research was the cause-and-effect relationships of the problems and prospects for the development of the construction industry both in Russia and at the global level in the context of the economic transformation of the world economy. In this paper, using SWOT data analysis, the strengths and weaknesses of the construction industry, threats and opportunities of the external environment in the modern conditions of development of both the Russian economy and the international market are analyzed. A working hypothesis of the study was formed. This hypothesis was tested in the framework of a scientific and practical seminar with the participation of representatives of universities that are engaged in the development of the construction industry, as well as with the participation of heads of construction companies. The article describes the current state of the construction industry in modern conditions of development both in Russia and abroad. A hypothesis is put forward about the impact of the crisis on the current state of the construction industry of the world market, measures are proposed to solve the identified problems of the development of the construction industry in Russia within the framework of the coordinated work of the authorities, universities of the country and business.
\end{abstract}


Keywords: Economic development; National economy; Construction works; Construction services; Dynamic industry; Market regulation.

\section{RESUMEN}

La relevancia del tema de investigación se debe a que las empresas constructoras en un período difícil en 2020 enfrentaron problemas de riesgo y muchas empresas constructoras se declararon en quiebra durante este período. La globalización del mundo moderno define desafíos cada vez más severos para las economías nacionales de todo el mundo. Teniendo en cuenta los patrones modernos de desarrollo de la economía mundial, es importante que la economía nacional de cada estado tenga una ventaja competitiva, gracias a la cual se desarrollará. El propósito de este artículo es analizar el estado actual de la industria de la construcción tanto en Rusia como en todo el mundo, analizar los problemas existentes y desarrollar medidas destinadas a resolverlos. Al estudiar la situación económica de esta industria, se consideraron indicadores como la dinámica del volumen. trabajos de construcción y la dinámica del número de organizaciones de construcción. Además, el trabajo identificó factores que limitan las actividades de las organizaciones de construcción y las perspectivas de desarrollo de la industria de la construcción tanto en Rusia como en todo el mundo. Este trabajo define acciones para resolver los problemas de la industria de la construcción, y también determina los resultados esperados de la implementación de estas medidas. La industria de la construcción también marca el nivel de desarrollo económico, es un sector muy importante en la economía de muchos países del mundo. El desarrollo de los servicios de construcción en todo el mundo ha ido ganando impulso en las últimas décadas y se está desarrollando de forma muy dinámica. Sin embargo, la industria de la construcción es muy sensible a fluctuaciones incluso menores en el mercado global. El tema de la investigación fueron las relaciones de causa y efecto de los problemas y perspectivas para el desarrollo de la industria de la construcción tanto en Rusia como a nivel mundial en el contexto de la transformación económica de la economía mundial. En este trabajo, utilizando el análisis de datos FODA, se analizan las fortalezas y debilidades de la industria de la construcción, las amenazas y oportunidades del entorno externo en las condiciones modernas de desarrollo tanto de la economía rusa como del mercado internacional. Se formó una hipótesis de trabajo del estudio. Esta hipótesis fue probada en el marco de un seminario científico y práctico con la participación de representantes de universidades que se dedican al desarrollo de la industria de la construcción, así como con la participación de jefes de empresas constructoras. El artículo describe el estado actual de la industria de la construcción en las condiciones modernas de desarrollo tanto en Rusia como en el extranjero. Se plantea una hipótesis sobre el impacto de la crisis en el estado actual de la industria de la construcción del mercado mundial, se proponen medidas para resolver los problemas identificados del desarrollo de la industria de la construcción en Rusia en el marco del trabajo coordinado de la autoridades, universidades del país y empresas.

Palabras claves: Desarrollo económico; Economía nacional; Trabajos de construcción; Servicios de construcción; Industria dinámica; Regulación del mercado.

\section{INTRODUCTION}

Considering the construction industry from an economic point of view, we can say that this industry has long been one of the most stable, demanded and dynamically developing industries in the Russian economy (Dakhaeva and Amirova, 2021). According to statistics, in 2020 the share of the construction industry in the GDP of our country increased to 5.74\% (Federal State Statistics Service, n.d). This industry shows advancing rates compared to the country's economy itself. So the country's GDP in 2020 increased by only $6.8 \%$ of the total growth rate of the gross domestic product, and the gross value added in the construction industry increased by $7.3 \%$. Despite the fact that in different periods the construction industry experienced both ups and downs, it remains one of the most attractive areas for investment, both private 
capital and large business. This can be explained by the fact that there are large volumes of dilapidated housing stock, as well as insufficient provision of housing for the country's population, poor development of the road network also underlies the development of the construction industry and related infrastructure, and the deterioration of many communications (Chekurdaev, 2018).

Such an increased interest in the industry can also be explained by the climatic conditions in our country, since construction is designed to improve the human environment. There is such a concept as construction - this is a type of economic activity that firmly occupies the sixth place in the structure of Russia's gross domestic product at the end of 2019 and makes most of the added value of manufactured products domestically.

Currently, banks are actively involved in developer programs, interaction with which guarantees buyers the receipt of housing on time (sometimes even earlier than the announced date) and at attractive interest rates. These developer projects have a profitability of over 20 percent. However, such profitability exists only in the central part of Russia. Thanks to the subsidizing of interest rates on loans to construction companies, this direction is being implemented (Kenchadze, 2020).

The construction industry is huge and consumes up to $10 \%$ of all money used in the world. On average, it can be assumed that every tenth able-bodied person in the world is somehow connected with the construction industry. The construction industry is partly the driver of the economy; many internal processes are tied to it. And although the construction sector adjusts rather than influences the development of our lives, the contribution of this industry to the development of social processes cannot be underestimated.

In addition, various changes in the regulation of the construction market occur on an ongoing basis, during the average cycle of construction of a residential building, such characteristics as: technical regulations, town planning legislation, legislation on shared construction change repeatedly.

According to its general characteristics, the construction industry is quite costly and at the same time allows providing a significant number of jobs to the population of the country. The dynamics of this industry - construction - is one of the main indicators of the socio-economic development of both the state as a whole and the regions separately, all this is an indicator of the development of a region or country as a whole. A balanced plan for the development of the construction sector is the most important task of the state, which contributes to the development of this direction within the framework of the general country.

The construction industry remains one of the most important economic sectors in Europe, representing about $10 \%$ of GDP and $50.5 \%$ of gross fixed capital formation, providing 20 million direct jobs in the EU alone.

The 2008 crisis hit the construction industry hard in Europe. Greece suffered the most and lost $80 \%$ of its construction industry between 2010 and 2013. In the rest of the EU, there was a sudden decline in production - from -54.4\% in Lithuania in 2009 to almost stable levels of activity in Germany and Austria (Pakhomov and Ovchinnikova, 2019).

Such close attention to the construction industry is also due to the climatic conditions of our country, at the same time, construction is aimed at improving the human environment, his life. Construction can also be defined as a type of economic activity that at the same time ranks sixth in the structure of Russia's gross domestic product at the end of 2019. This industry creates a significant added value of products manufactured in the country. The contribution of the construction industry to the economy of the state is more than $6 \%$, in monetary terms -5.3 trillion rubles. 
Currently, commercial banks are actively involved in developer programs, their profitability exceeds $25 \%$. But this dynamic is characteristic only for the central part of Russia. The rest of Russia is not as profitable. And if there is no support from subsidizing interest rates on loans to developers, it will be difficult to implement such tasks.

In addition, changes in the regulation of the construction market are carried out on an ongoing basis and it turns out that during the average construction cycle, all technical regulations and legislation change repeatedly.

By its characteristics, the construction industry is quite capital-intensive and due to this industry additional jobs are provided for the population of the country. And also the relationship with other sectors of the economy makes it possible to form a multiplier effect of this industry, that is, with an increase in the volume of work performed, a corresponding increase in costs for intermediate products occurs, which leads to an increase in production in other sectors. The dynamics of the volume of construction activity can be considered one of the key indicators of the socio-economic development of both regions and the state as a whole. The digest of materials from the American portal Construction Dive lists the main vectors that will develop in construction in the near future. The construction industry is the second largest in the United States. But this does not mean that this area is quite stable - we can say that trends are constantly changing, and the market fluctuates. Construction Dive identified the main directions of 2021, along which the industry will develop (Beeton, 2020).

1. Minimization of the very risks of destruction of buildings and, most importantly, an emphasis on safety. In 2019, there were several major building collapse cases in the United States, followed by lawsuits. This influenced insurance companies to analyze risks more thoroughly.

2. The growth of modular construction. Last year, the construction of structures using modules began to gain mass character - this method is simpler and faster, it is characterized by high strength and safety. While modular construction in the United States occupies 5\% of the market, however, it is in the spotlight. Experts believe that in 2021 the active development of this method will continue and customers will pay more attention to its advantages.

3. Distribution of labor. There is a lack of professionals in the construction industry. Because of this, American developers have to hire subcontractors and spend more money. Therefore, the United States is going to create a wide network of contractors, which will provide jobs for local developers and large developers throughout the country.

4. Automation. The construction industry, like any other, is now striving to automate activities and reduce the number of jobs. According to Volvo, more than 10 thousand robots for developers will be created by 2025 .

5. Reconsideration of high risk contracts. One of the biggest problems for contractors is the strictly fixed terms of the contract. It is well known that during the construction of large facilities force majeure situations often occur, which result in postponement and additional costs. Because of this, there are often constant disputes between the customer and the developer (Beeton, 2020).

To consider the stated problem and its visual presentation, as well as the development of measures and their implementation, various sources were analyzed, both in Russian literature and foreign sources.

The analysis of individual problems of management of construction projects was facilitated by the works of such scientists as: Asaul A.N., Kaminskiy A.L., Ivakin E.K., Korobko V.I., Stepanov I.S., Fedotov F.M., Robotov A.S., Chernyak V.Z., Yunatskevich P.I. and others. 
In the framework of the scientific analysis of various features of research in the design construction business, as well as their practical significance, the works of such scientists as: Bravermann A.A., Wijk van der G., Aaker D., Golubkov E.P., Melnikova O T., Smith P. R., Malhotra N. K., Stephen E., Timofeev M. I., Churchill G. D., Tretyak O. A. and others (Ministry of Science and Higher Education of the Russian Federation, n.d).

The analysis of the degree of elaboration of the specified problems made it possible to identify the range of unaffected problems that relate to project management in construction, as well as the possibility of applying the research results in the practical activities of construction organizations.

\section{ANALYSIS OF THE CURRENT ECONOMIC SITUATION IN THE CONSTRUCTION INDUSTRY}

The construction industry plays a key role in the socio-economic development of both the country and the region, being an important indicator of its stability, and it is also the basis for the continuous development of the national economy, while solving the housing problems of the population and raising the cultural level of the people (Kenchadze, 2020).

To conduct a statistical analysis of the economic situation in the construction industry, a period was set for the last 5 years. The main dominant indicators reflecting the economic development of the construction industry are:

- the total volume of operating organizations;

- the amount of work performed on the economic activity of construction;

- the volume of investments in fixed assets of construction organizations.

Consider the performance of the construction industry as of December 2020. The table below shows data for the period from 2016 to 2020, for the analysis of construction activities in our country (Table 1) (Pustovgar et al., 2018).

Table 1. Dynamics of indicators characterizing the economic situation of the building industry in Russia in 20152020

\begin{tabular}{|c|c|c|c|c|c|c|}
\hline \multirow{2}{*}{ Year } & \multicolumn{2}{|c|}{$\begin{array}{c}\text { Number of active construction } \\
\text { organizations }\end{array}$} & \multicolumn{2}{|c|}{$\begin{array}{l}\text { The amount of work } \\
\text { performed by the type of } \\
\text { economic activity } \\
\text { "Construction" }\end{array}$} & \multirow{2}{*}{$\begin{array}{c}\text { Average } \\
\text { amount of } \\
\text { work } \\
\text { performed by } \\
\text { one } \\
\text { organization } \\
\text { (million } \\
\text { rubles) } \\
\end{array}$} & \multirow{2}{*}{$\begin{array}{c}\text { Investments in } \\
\text { fixed assets of } \\
\text { construction } \\
\text { organizations } \\
\text { Growth rate, } \% \text { to the } \\
\text { previous period }\end{array}$} \\
\hline & $\begin{array}{c}\text { incl. private } \\
\text { organizations } \\
\text { (units) }\end{array}$ & $\begin{array}{l}\text { Share of private } \\
\text { organizations, } \%\end{array}$ & $\begin{array}{l}\text { incl. private } \\
\text { organizations } \\
\text { (units) }\end{array}$ & $\begin{array}{c}\text { Share of } \\
\text { private } \\
\text { organizatio } \\
\text { ns, } \%\end{array}$ & & \\
\hline 2016 & 223002 & 98,32 & 5500,4 & 89,80 & 24,66 & 107,12 \\
\hline 2017 & 233140 & 99,06 & 5539,7 & 79,02 & 23,76 & 85,49 \\
\hline 2018 & 269548 & 99,24 & 5733,6 & 79,59 & 21,27 & 110,6 \\
\hline 2019 & 276944 & 99,09 & 5888,4 & 78,03 & 21,26 & 100,5 \\
\hline 2020 & 291345 & 99,75 & 6076,8 & 78,19 & 20,86 & 102,00 \\
\hline
\end{tabular}

In general, the dynamics of indicators can be traced positive, there is an increase in the number of operating construction organizations, and an annual increase for the period 2016-2020. averages 5.63\% 
per year. We also note that the growth of private construction companies for the period 2016-2020. amounted to $54.67 \%$, that is, the private sector grew at a faster pace, but the dynamics in recent years has been regressing, with an average annual growth rate of $6.28 \%$ per year over the period under review, but over the past three years $-4.97 \%$ in year. The growth in the volume of work performed amounted to 8,279 billion rubles, it should be noted that the main growth was achieved again at the expense of private organizations (Federal State Statistics Service, n.d). An analysis of the above indicators allows us to deduce such a pattern that the process of consolidation of private business is $12.17 \%$. The volume of work annually grows by $15.45 \%$ on average, but it should be noted that in recent years the growth rate in construction has also been decreasing, and the average germination rate for the last 2 years was only 2.99\% (Pakhomov and Ovchinnikova, 2019).

\section{DISCUSSION}

In connection with the situation in the world, construction felt the consequences of the crisis, these negative consequences affected investment programs that require large financial resources and, which is important, their stable income. Due to the lack of these financial resources, started objects are frozen, the date is postponed earlier than the scheduled date of commissioning. The receipt of orders has a negative impact on the position of all contractors, as well as on enterprises that produce construction materials. Many of them turned out to be unprepared for crisis situations and they do not have an anti-crisis program to overcome critical conditions. Some contractors attempted to mothball construction projects, or ceased their activities, the rest of the enterprises reduced the number of their staff, or switched to part-time working weeks.

From the beginning of autumn 2020, we can expect a downturn in the construction industry, which will probably hit the economy more than the 2008 crisis. With the preservation of permanent quarantines and the development of infrastructure for remote work, the demand for office premises, the supply of apartments near these offices, commercial space and offline shopping centers in cities will decrease (Pakhomov and Ovchinnikova, 2019; Dakhaeva and Amirova, 2021).

Even before COVID-19, the performance of the construction industry was low compared to other sectors of the economy. According to the level of digitalization, only comrades working in the agricultural industry stand behind the builders, and therefore the construction industry has nowhere to retreat (Beeton, 2020).

1. Stagnant productivity, low data digitization and low profitability (2-10\% in developed countries, and $15-30 \%$ in developing countries) have plagued the industry for years. A highly individual approach to construction and a fragmented ecosystem only adds to the problems that hinder the development of the entire sector.

2. Over the past decades, the amount of data used in planning - grew like an avalanche, while the incoming data was not only not processed, but later was rarely systematized, forever lost on local disks. Therefore, at the moment the construction industry is one of the least digitized sectors of the economy.

Already now you can work from any convenient place and sell / buy any goods from anywhere in the world where you can catch the Internet. In this crisis, new companies and start-ups will begin to grow, which will lead us to a new level of consumption and the possibility of making money until the next big crisis.

Unfortunately, a construction project cannot be compared to an average IT startup. Kanban for a standard IT project will have 100 times fewer tasks than Kanban for building a small outdoor pool. The construction industry is much more complex and confusing than banking (100x) or autonomous cars 
(10x), so it's still a long way to apply big data and machine learning in project planning to give the industry a boost.

The construction industry lags behind other sectors - because it is large and heterogeneous and it will take many more years for it to catch up with the level of automation that, for example, mechanical engineering has already reached today.

3. One of the main challenges faced by the construction industry compared to other industries is low productivity. At the same time, $78 \%$ of engineering and construction companies believe that the risks in the design of new projects have increased several times (Beeton, 2020).

The deterioration of this financial position of enterprises in the construction industry is mostly caused by objective factors. For example, high inflation has driven the entire rate of interest on a loan, which may well exceed the estimated estimated cost of most projects. All this made medium-term and long-term loans absolutely inaccessible. Also, a high level of taxes, collection of debts of enterprises for payments all this was the reason for the difficulties in the economic activities of enterprises (Pustovgar et al., 2018).

The main problems identified in the construction industry during the crisis are the following definitions:

- Lack of demand for the construction industry from sellers and high mortgage rates;

- People's distrust of construction;

- Lack of government support;

- Underdeveloped engineering infrastructure.

In this regard, we can say that the development of construction is realized from three phenomena: the financial system, state support, infrastructure. Only when these three vectors are simultaneously triggered will the industry begin to operate effectively.

The following steps should be taken to address the problems of the construction industry's ineffective new action:

- to stimulate mortgage lending, to make loans available;

- development of state financing of housing programs;

- construction of state business incubators to provide space;

- opening of construction technology parks in the regions;

- development of infrastructure systems in municipalities;

- development of low-rise construction.

Nowadays, they are more and more careful and cautious about launching new business projects. Based on the fact that the main guarantor of the success of this vector of development is primarily the developer's reliability, as well as the pace of construction and an acceptable pricing policy. The lack of demand for the construction market is primarily due to the instability of the entire economic situation in the country and in the regions in particular: people are afraid to make such important decisions without having stability in the 
future. It can be seen that many potential buyers do not enter into deals because they expect property prices to decline. At the moment, the demand for construction objects is low, but real estate is currently a profitable investment in an already completed real estate object or an object on the secondary market. Some bursts of activity will be temporary and localized. Also, most companies, in order to revive their sales, offer various options for promotions and installments. The amount of this discount varies from certain conditions and ranges from 5\% to $40 \%$. According to forecasts of competent sources, in the near future there is a fluctuating price dynamics in the range of $1 \%-5 \%$ per month, possible both in the positive and in the negative direction, depending on the segment of the construction market (Dakhaeva and Amirova, 2021). At the same time, the dynamics of price growth will continue to be in the segment of the most demanded one- and two-room apartments, three-room and multi-room apartments may lose in price.

The construction industry has also seen a sharp drop in demand for housing, as well as for construction and renovation work, and, as it should be, for construction equipment and materials. The logical chain goes further - the drop in demand is due to the fall in the consumer's solvency, due to the emergence of certain difficulties with the provision of loans, benefits for real estate.

To improve the crisis situation in the construction industry, the following definitions of perspective are proposed:

- demand in the housing construction market;

- increasing the availability of purchased housing;

- government subsidies in support of housing construction;

-allocation of funds within the framework of anti-crisis programs, to the construction industry and its crediting;

-development of a whole range of anti-crisis measures to provide jobs and support construction enterprises.

Also, for the rapid development of the industry, it is necessary at the federal level to consider the creation of leasing structures and banking institutions in the construction sector on the example of the successful implementation of such instruments in the agro-industrial complex (JSC Rosselkhozbank and JSC Rosagroleasing) (Research and Markets, 2020).

In the future, there should also be a lot of qualitative changes in housing under construction. First of all, a transition will be made to the design and construction of houses from environmentally friendly materials. The volume of construction of private family houses in suburban areas and in rural areas will increase to $50 \%$. In the near future, residential buildings of superior comfort will be built in cities. To solve the problem of social, including free housing, the existing housing stock will be used to increase the level of comfort of apartments, the environmental safety of the residential area and the development of social services facilities in it.

\section{CONCLUSIONS}

Based on the analyzed data, it is possible to conclude that the dynamics of the indicators of the construction industry is an unstable sphere: at the moment there is a decrease in the pace of the construction sector, there is a decrease in investments in the modernization of the construction industry, a high rate of decline in the renovation of building objects of social and cultural significance. The problems 
and limitations of this development of the construction industry lie in the fact that mainly in the low activity of the emergence of private construction organizations, also in the decrease in investment in the construction industry, in the absence of a number of opportunities for private business, in the implementation of all social projects with a long-term payback, in an unworked system ongoing structuring, selection and evaluation of construction projects.

It was also concluded that in the conditions of the financial crisis, for the successful development of the construction industry, it is necessary to implement certain mechanisms of interaction at all levels educational organizations, authorities and business.

The study carried out in the article showed that if the very state of housing construction in Russia can be assessed as stable with a small number of decreasing indicators over the past 2 years, the dynamics of indicators of the state of building objects of social and cultural significance in Russia for 2016-2020 has a negative trend, so for the selected period there is a decrease in the commissioning of socially significant facilities for educational institutions: on average by $2.26 \%$ per year, we note that over the past two years, a decrease by $15.70 \%$, a decrease in the commissioning of healthcare facilities approximately $3.06 \%$ every year (Dakhaeva, 2021).

One of the most realistic options for overcoming the crisis in this industry is the development and improvement of mechanisms for regulating public-private partnership (PPP). In order to develop this direction of PPP, it is necessary to apply a number of measures: - create project teams that would be responsible for project support; - Apply comprehensive programs to support PPP projects; -Continuously monitor and keep abreast at all stages of project implementation; - to create a regulatory and legal framework for the development of projects in the construction industry, in which it would be acceptable for business to fulfill the obligations of all agreements, also to form a system of effective forecasting, effective administrative and regulatory regulation, improving the quality of development, evaluation and implementation of projects.

Thus, our hypothesis about the successful development of the construction industry through the interaction of mechanisms at all levels (educational organizations, authorities and business spheres) is successful and applicable in the context of modern economic development.

\section{REFERENCES}

Beeton, L. (2020). Construction Dive Top trends: 5 ways construction will evolve in 2021. Constructiondive. Retrieved from: https://www.constructiondive.com/news/top-trends-5-waysconstruction-will-evolve-in-2020/569472/

Chekurdaev, V. S. (2018). Housing fund of Russia: problems and development prospects. International Journal of Humanities and Natural Sciences, 4, 247-251.

Dakhaeva, F. (2021). Large Cities in the process of new industrialization. SHS Web of Conferences, 95, 05015 .

Dakhaeva, F. and Amirova, A. (2021). Socially-oriented economy as part of the macroeconomic development system. SHS Web of Conferences, 94, 01021.

Federal State Statistics Service. (n.d). Retrieved from: www.gks.ru

Kenchadze, D. D., ed. (2020). Construction in Russia. 2020: Statistical collection. Moscow, Russia: Rosstat. 
Ministry of Science and Higher Education of the Russian Federation. (n.d). Retrieved from: minobrnauki.gov.ru

Pakhomov, E. V. and Ovchinnikova, M. S. (2019). Current state of the construction industry in the Russian Federation. Young Scientist, 2 (240), 255-260.

Pustovgar, A. P., Leibman, M. E., Medvedev, V. V. and Adamtsevich, A. O. (2018). The state of the building complex in the Russian Federation 2017. Moscow, Russia: Moscow State University of Civil Engineering (National Research University).

Research and Markets. (2020). Global Construction Industry Report 2020: 40+ Market Segments, Opportunities in Top 100 Cities, and Risk Assessments. Intrado. GlobeNewswire. Retrieved from: https://www.globenewswire.com/news-release/2020/09/25/2099196/0/en/Global-Construction-IndustryReport-2020-40-Market-Segments-Opportunities-in-Top-100-Cities-and-Risk-Assessments.html 